\title{
POLISH ACADEMIC ONLINE JOURNALS CONNECTED WITH JOURNALISM AND MEDIA. THE CHARACTERISTICS OF JOURNALISM GENRES.
}

\author{
Joanna Mikosz ${ }^{1}$
}

\begin{abstract}
The article presents academic Polish online journals which focus on media and journalism. In the first part, the author discusses the history of Polish academic publications and the profiles of chosen journals. The second part of the article describes the characteristics of journalism genres as they appear in journals.
\end{abstract}

Key words: Polish online journals, Polish academic journals

\section{Introduction}

The beginning of the academic press in Poland dates back to the $19^{\text {th }}$ century. The weakness of national science at the time, with only a small circle of people involved in it, meant that academic journals were not of a very high level, nor did they have original content. The poverty of intellectual life and the lack of universities meant that in the first decade after the November Uprising of $1883^{2}$, the tendency to only celebrate the achievements of the leading centres of academic life abroad, mainly in Germany, France and England, prevailed in national journalism. Over the years, the situation improved, and academic journals began to be revived, with more and more native works being published in them. This breakthrough was already visible in the mid-1830's both in the Kingdom of Poland and in the borderlands, and could be seen crealy on the pages of certain journals e.g. Wizerunki i Roztrzasania Naukowych (Academic Images and Debate), Muzeum Domowe (Home Museum), Pamiętnika Sztuk Pięknych (Diary of Fine Arts), Atheneum as well as the Przeglad Naukowy (Academic Review) (Łojek, 1976, p. 181). These trends deepened further with the easing of political repression and general development of journalism in the 1840s. This was followed by the stimulation of cultural life in the country, and some (though to a limited extent) academic institutions were also restored. Moreover, an interesting initiative, going beyond the university structures, was

1. PhD at the University of Lodz, Department of Journalism and Social Communication, Lodz, Poland, e-mail: mikoszj@wp.pl

2. The November Uprising in Poland (1930-1931). 
the creation of an academic society by members of the editorial staff of the Biblioteka Warszawska (Warsaw Library) in 1859.

As Jerzy Łojek stresses: "the negative feature of academic journalism was its one-sidedness. Journals were mainly devoted to social and theoretical sciences, as well as humanities sections in general-interest magazines" (Łojek, 1976, p. 181).

It is also worth presenting the findings of Danuta Hombek, who claims that: the proper development of academic journals began with Polnische Bibliothec (Polish Library), edited in Gdansk in 1718-1719 by Gotfryd Lengnich - a historian who was also the author of most of the printed texts (Hombek, 2016, p. 66). The periodical was supposed to "provide reliable academic information, making a critical review of false, legendary opinions about our past and reveal the historical truth" (Hombek, 2016, p. 66). In his publications, the author was sceptical about medieval historiography.

Torun was the second centre of academic publishing, according to the researcher. In the first half of the eighteenth century, Jerzy Piotr Schulz began to publish the journal Das Gelehrte Preussen (The Prussian Scholar) (1722-1725). The editor collaborated with many authors, professors from schools in Torun, as well as Elbląg, Gdańsk and Królewiec. The journal provided varied information on academic life (Hombek, 2016, p. 66). In Toruń, the Pressische Todes-Temple (The Todes-Temple Press) (1728-1730), edited by Jerzy Piotr Schulz, was also published. The periodical was historical (Hombek, 2016, p. 67).

The third publishing centre was Warsaw. In the years 1753-1755, on the initiative of Mitzer de Kolof, a journal dealing with nature and medicine titled Warschauer Bibliothek (Warsaw Library) was published, and in the years 17551763 Acta Litteraria Regni Poloniae et Magni Ducatus Lithuaniae (Literary Act of the Polish Crown and the Grand Duchy of Lithuania) was also published there (Hombek, 2016, p. 68).

In the $1850 \mathrm{~s}$, there were journals devoted to academic issues, and even such specializing in specific fields of knowledge, as, for instance: Bibliografia Krajowa (National Bibliography) from 1856 (Lojek, 1976, p. 182). It is worth adding that in the period under discussion, alongside academic articles, popular science publications were printed. However, the academic and popular science functions of this period overlapped, which was "a reflection of the weakness of the journals of the first decade after the November Uprising" (Lojek 1976, p. 182).

Up to 1905, an important role in organizing and inspiring academic research was played by monthly journals of an encyclopaedic nature: Biblioteka Warszawska (Warsaw Library) (1841-1915), Atheneum (1876-1901) and Przeglad Filmowy (Film Review) (1896-1949). In these periodicals, not only mathematicians 
and naturalists, but also doctors and economists published their works. Wista (Vistula) (1887-1916), a geographical and economic periodical, and Przeglad Pedagogiczny (Pedagogical Works) (1885-1939) also had an influence on the development of academic life in the period. Part of the pedagogical body until 1882 was Przeglad Pedagogiczny (Pedagogical Review) (Lojek, 1976, p. 103). As Jerzy Łojek emphasizes the natural sciences were developed thanks to positivist propaganda. The titles include: Przyroda i Przemyst (Nature and Industry) (1872-1881), Gazeta Lekarska (Medical Gazette) (1866-1939), Kronika Dentystyczna (Dental Chronicle) (1908-1939) and Neurologia Polska (Polish Neurology) (1910-1917) (Łojek, 1976, p. 104).

The researcher emphasizes that "it was a time of rapid development in comparison with the years preceding this period" (Łojek, 1976, p. 302). Academic journals in terms of the number of titles published - were the largest group of periodicals next to general-interest periodicals (Łojek, 1976, p. 302). The confirmation of this hypothesis is statistical data revealing that in 1926, 216 academic journals were issued, in 1930 - 284, and in 1935 - 400 (Lojek, 1976, p. 302).

However, journals representing the social sciences had a dominant position, while mathematics and natural sciences were poorly represented (Lojek, 1976, p. 303). Until the end of the 1920s, publishing activities were conducted by higher education institutions, academic societies and academic institutes, not directly related to the didactic work of academic schools.

After the outbreak of World War II, the underground press emerged in Poland. The press at that time "lost its character solely as a tool of information and apolitical struggle against the enemy, turning to the ideological and political upbringing of society and clearly taking on the characteristics of a political press" (Myśliński, Władyka, 1988, p. 149). The secret press also had sociocultural, educational or even professional functions, allowing survival of the period of war without the functioning of the institutions of an independent state. Examples include: Sztuka i Naród (Art and Nation) (1942-1944), Przełom (Breakthrough) (1942-1943), Miesięcznik Literacki (Literary Monthly) (19421943) or Kultura Polska (Polish Culture) (1943).

1945-1952 were the organizational/publishing years when the pre-war academic journals were re-established. During this period, new titles were also set up, in accordance with the then requirements resulting from the politicalconstitutional transformations. At that time, the tenets of Marxist philosophy and science were popularized, which was evident, for example, in the journal Nowe Drogi (New Paths) (1946-1948) (Maślanka, 1976, p. 49). According to statistics in 1973, 1417 academic journals were published in Poland. They were devoted to engineering, technology, industry, construction, medicine, economic sciences, as well as history and literary studies. The publishers included: the Polish Academy of Sciences and its individual institutions, colleges, specialized 
academic societies, departmental institutes of the Polish Academic Publishers, the Ossoliński/ Ossolineum State Publishing House (Maślanka, 1976, p. 49).

In the 1990s, Poland moved away from state media which was subject to state control. Starting from 1989, the Polish media market changed drastically, which marked the largest and most extensive changes in the entire 20th century. The changes in Poland after the political transformation included the collapse of communism and the opening of the borders with Western European countries. New legal regulations concerning the publishing press were passed in 1990 and they included: the abolition of censorship and liquidation of the Central Office for the Control of Press, Publications and Cultural Events. The previous licence-based press system was transformed into a registration-based one and thus the only condition for the publishing of a newspaper became the court registration of the title, which accelerated the establishment of new papers whose existence depended on the market only. Besides, under a parliamentary resolution, the communist concern RSW - Prasa-Książka-Ruch (Press-BookMovement) was dissolved, which meant the end of the state monopoly in the field of distribution and, consequently, all the papers published by RSW were sold to companies owned by Polish and foreign publishing houses. In 1992, the Law of Broadcasting was passed ${ }^{3}$. Subsequently, other laws adjusting Polish law European Union law were enacted. In 1997, the new Polish Constitution was introduced. According to it, the freedom of the press and other media in Poland was guaranteed. Censorship and licensing of the press was prohibited, yet licensing of broadcasting was accepted. Press titles had only to be registered in court. ${ }^{4}$

3. The Broadcasting Act made possible the launch of private, commercial radio and television stations.

4. Political transformation brought a lot of new rules to the Press Market. We can point out the following changes:

- Polish press, for the first time since 1945, was able to fully develop and express different points of view and opinions as well as provide information that was previously left unspoken (such as social protests);

- previous "underground" papers (like for example: the Roman-Catholic Church press) as well as the papers published abroad began to be published officially (for example: Kultura (Culture);

- Poland also started to be an attractive investment destination for foreign companies from many countries like: France, Germany, Italy or Scandinavia. We can indicate for example such companies as: Orkla Media, Passauer Neue Press or Jurg Marquard;

- in Poland there also appeared Polish press companies like Agora, which was established in 1989 by Andrzej Wajda, Aleksander Paszyński and Zbigniew Bujak;

- the number of newspapers and magazines increased by almost half, from 3,007 in 1990, to 4,340 in 1995 . By 2001, there were already 5,837 press titles - nationwide and local ones (Filas, 1999, p. 112);

- in the Press Market there appeared new newspapers - one of the most important was 
After the political transformation, thanks to the invasion of large western press and publishing groups, many new press titles were created in Poland. As Zbigniew Bajka explains: "after the collapse of the communist system, 800 titles from the academic and popular-science press emerged in Poland" (Bajka, 2012 , p. 187). Among them were periodicals appearing irregularly, as well as quarterlies and yearlies (Jarowiecki, 1995, p. 184).

The political changes in the country, and hence the transformations in the press market, coincided with the IT revolution. The Internet has become not only a source of information, a communication tool, but also a platform on which it publishes, among other things, the electronic press. The transfer of journalistic

Gazeta Wyborcza (Electoral Gazette) - the first totally independent newspaper in postcommunist Poland" (Oniszczuk, 2010, p. 197);

- the cultural changes led to the rise of the commercial mass press (for example: Super Express) based on tabloids: as well as sensational and erotic magazines addressed to the reader who expectis rather unrefined entertainment;

- the transformation also led to the vulgarization of the media and brutalization of the language (the weekly Nie (No) published by Jerzy Urban);

- the political changes after 1989 also brought changes to the situation of social-cultural magazines in Poland. Titles connected with the previous system no longer exist; there appeared many new titles (most of them influenced by the process of commercialization). In this group we can distinguish film, theatre, art, photography and music magazines like: Machina (Machine) Film, Wiadomości Kulturalne (Cultural News) or Notatnik Teatralny (Theatrical News) (Fiut, 2000, p. 64-66);

- on the other hand, elegantly illustrated magazines were published (for example: Twój Styl (Your Style) magazine for women), addressed to wealthier people;

- magazines for young people which were edited before 1989 Płomyk (Glimmer) began to lose popularity. Their place was taken by colourful magazines edited abroad like Popcorn or Dziewczyna (Girl) which did not have any educational or didactic value;

- besides, there appeared a number of magazines connected with new parties and political groups, for example: Gazeta Polska (Polish Gazzete) (centre-right circles). The catholic press, such as Niedziela (Sunday) (Częstochowa); or Gość Niedzielny (Sunday Guest) (Katowice) also won substantial readership;

- specialized titles like Komputer Świat (Computer World), Dom i Wnętrze (Home and Interior), Magazyn Budowlany (Buliding Magazine) also started to be printed (Fiut ,2000, p. 66);

- the abolishment of state monopoly along with the privatization after 1989 led to the creation of a politically diversified press market. The law of supply and demand began to work there, which resulted in competitiveness. This, in turn, made the publishers adapt to the tastes and expectations of the readers. The content and graphic formula of papers got more attractive as well. The computerization of editorial offices after 1990 led to new technologies and made possible the editing of newspapers and magazines in accordance with the highest European standards;

- diversity in terms of subjects, typography and political allegiances leads to publisher competitiveness in terms of: modern layouts, advertising becoming the main source of income, special interest supplements like, for example Budownictwo (Buliding) or Motoryzacja (Motorization) added to Dziennik Łódzki (Łódź Daily). 
forms to the communication space of cyberspace can be considered in a variety of ways. The costs of publishing journals on the web are lower than the printed versions. The advantages also include lower prices or free access and the speed of publishing texts. In addition, it is possible to link to other websites on the Internet while reading, adapt the font to the individual needs of the reader and combine in one message content transmitted by text, images (photos, videos) or audio. Undoubtedly, the technological factors influence the variety of forms: "The net creates the possibility of combining all traditional media together: the recipient decides which channel of contact with the content he will choose" (Bauer, 2015, p. 82).

We can divide the online press into two groups: journals that only exist in electronic form ${ }^{5}$ and journals that appear online in identical version to paper journals (Pisarek, 2006, p. 155).

\section{Previous research in the field}

Academic journals are special-issue journals and general-interest magazines for disseminating knowledge to a wide audience, in colloquial terms - magazines popularizing knowledge (Maślanka, 1976, p. 50). Their aim is to disseminate the original results of academic research. They are issued by academic institutions and are intended for the academic community. Julian Maślanka adds: "they play an important role in the process of integrating the circles of people professionally connected with science. They are characterized by a large range of regularity and a consistent graphic layout, format, arrangement of internal sections, volumes of individual issues (numbers, volumes)" (Maślanka, 1976, p. 47).

Academic journals have been and are being analyzed by researchers. Among the studies on the history of the Polish press, in which we can include academic journals, we can point out : Prasa polska 1661-1864 (Polish press 1661-1864) (Łojek, 1976), Prasa polska 1864-1918 (Polish press 1864-1918) (Łojek, 1976), Prasa polska 1918-1939 (Polish press 1918-1939) (Łojek, 1980), Prasa polska 1939-1945 (Polish Press 1939-1945) (Łojek, 1980), Dzieje prasy polskiej do 1795 (History of the Polish press until 1795) (Hombek, 2016), Dzieje prasy polskiej (History of the Polish press) (Łojek, Myśliński, W. Władyka, 1988) and Encyklopedia wiedzy o prasie (Encyclopedia of knowledge about the press) (Maślanka, 1976). In addition, we can include: Transformacja prasy polskiej $w$ latach 1989-1994 (Transformation of the Polish press 1989-1994) (Jarowiecki,

5. It should be added that the oldest Polish academic journal (peer-reviewed) has been published continuously since 2001. and is called Kultura i Historia (Culture and History) published by the Maria Curie-Skłodowska University of Lublin. Retrieved from (http:// www.kulturaihistoria.umcs.lublin.pl/czasopismo). 
1995), as well as Rynek mediów w Polsce (Dziennikarstwo i świat mediów, 2012) (the Media Market in Poland (Journalism and the Media World, 2012)).

It should be emphasized that there has been no academic publication so far that has presented journalistic genres appearing in the pages of Polish academic journals in electronic or printed version related to journalism and media science. The above studies are therefore pioneering. Very useful for research into journalistic genres appearing in the pages of academic journals available on the Internet are the following studies: Gatunki prasowe (Press genres) (Wojtak, 2004), Analiza gatunków prasowych. Zręby teorii i elementy dydaktyki (Analysis of press genres. Foundations of theory and elements of didactics) (Wojtak, 2006), Gatunki dziennikarskie w Sieci. Co się zmienito i jak bardzo (E-gatunki. Dziennikarz w nowej przestrzeni edukacyjnej, 2015) (Journalistic genres on the Net. What has changed and how much (E-genre: Journalist in the new educational space, 2015)), and also O artykule naukowym stów kilka (A few words about the academic article) (Wolańska, 2008).

\section{Research Questions}

The aim of the undertaken research was to determine what journalistic genres appear on the pages of Polish academic journals available on the Internet, where the subject is journalism and the media. The query confirms the hypothesis put forward by Julian Maślanka that: "in academic journals there are the following journalistic genres: articles and dissertations, reviews, chronicles, polemics and reports (Encyklopedia wiedzy o prasie, (Encyclopedia of knowledge about the press) 1976, p. 50). However, not all of the listed genres can be found in the analysed editions of academic publications found on the Internet. This is due to the fact that only the current issues from the most recent editions of the periodicals were examined. The rich exemplification of a given journalistic genre stems from the issues to which a specific edition of the journal was devoted.

\section{Methods}

Among the many methods and research techniques used during the writing of this article - due to the way in which the topic is constructed. The historical method was used - which we owe primarily to the possibility of chronological and thematic ordering, embedding analysis of its activities and determining the status in specific historical circumstances and the accompanying social, political, economic and cultural conditions. The fundamental method used in the description and characteristics of the academic press appearing in cyberspace is the analysis of its content, which amounts to identifying the subject, method and form of the message. A self-constructed categorization key was used for the research. It contains categories referring to the content and form of the message. 
Apart from the thematic threads that appeared in the selected magazines, journalistic genres were also researched. The following were used as units of measurement: a sign (to study the subject) and a statement (to study the genre).

\section{Data Analysis}

Among the Polish academic journals dealing with media and journalism, one can distinguish journals that appear only in the printed version, those both printed and available online, and those issued only in cyberspace. However, it should be added that the academic journal is a press title, therefore it must operate in accordance with the provisions of the Act of 26 January 1984. Press law (Journal of Laws 1984, No. 5, item 24, as amended) and the Regulation of the Minister of Justice from 9 July 1990 on the register of newspapers and magazines (Journal of Laws of 1990, No. 46, item 275), which means that:

- it was registered in the district court competent for the publisher's registered office, and thus entered in the register of newspapers and magazines;

- the journal data submitted to the register of journals and magazines is current: title, name of the publisher, seat and address of the editor and publisher, details of the editor-in-chief, frequency of publishing;

- it has a permanent title;

- it appears at specified intervals, not more often than once a week and at least once a year;

- each issue contains the date and designation of the ISSN number ${ }^{6}$.

- according to data presented by the Ministry of Science and Higher Education, academic journals are divided into the following groups:

6. The academic journal has an ISSN number, and the publisher operates in accordance with the Act of 7 November 1996 on obligatory library copies (Journal of Laws of 1996, No. 152, item 722) and the Regulation of the Minister of Culture and Art of March 6, 1997. on the list of libraries entitled to receive obligatory copies of particular types of publications and the rules and procedure for their transmission (Journal of Laws 1997, No. 29, item 161), which means that: 1 . The journal has an ISSN number assigned to each journal carrier (e.g. print version, online). 2. The Publisher regularly provides the eligible libraries (indicated in the Act and Regulation) with obligatory copies immediately after their publication: the National Library up to 5 days from publication, and the remaining eligible libraries up to 14 days from publication. 3. In the case of an electronic journal, the publisher submits a file with a new issue of the journal to the Digital Library Repository up to 5 days from publication. ISSN - The basic identifier, which should be taken care of by the publisher of the journal, is the International Standard Serial Number, or ISSN. https:/www.rpo.gov.pl/ sites/default/files/Wyst\%C4\%85pienie\%20do\%20Ministra\%20Nauki\%20i\%20\%20Szkolnictwa\%20Wy\%C5\%Bcszego\%20ws.\%20czasopism\%20naukowych.pdf (2019, April 20). 
- academic journals with impact factor (IF) ${ }^{7}$, located in the journal citation reports database (JCR) along with the number of points awarded for academic publications in these journals. There are 11737 titles in this group ${ }^{8}$.

- academic journals without an impact factor (IF) factor along with the number of credits awarded for academic publications in these journals. There are 2209 titles in this group ${ }^{9}$;

- in the European reference index for the humanities (ERIH) database, along with the number of points awarded for academic publications in these journals. According to the data, there are 4197 titles $^{10}$.

A source of information on academic journals is also ARIANTA, a database of academic and professional Polish e-journals ${ }^{11}$. The number of academic journals registered in the database is $3080^{12}$.

Among the titles of journals publishing academic content related to journalism and media studies are: Acta Universitatis Lodziensis. Folia Litteraria Polonicathe journal is a quarterly (articles are also available in online version) published since 1998 by the University of Lodz Publisher. The periodical presents results from two research areas - in addition to issues related to literary studies, it also publishes content related to journalism and media science ${ }^{13}$;

- Acta Universitatis Wratislaviensis. Journalism and Media - the journal has been published since 2010 in its printed version, and since 2011 also in electronic form. The periodical comes from the University of Wroclaw and is being developed by the Institute of Journalism and Social Communication.

7. The Impact Factor identifies the frequency with which an average article from a journal is cited in a particular year. You can use this number to evaluate or compare a journal's relative importance to others in the same field or see how frequently articles are cited to determine which journals may be better for your collection (http://impactfactor.pl/).

8. Retrieved from (http://www.bip.nauka.gov.pl/g2/oryginal/2017_01/1ec97396461f9c95e4 af247a813246bf.pdf) (2019, April 22).

9. Retrieved from (http://www.bip.nauka.gov.pl/g2/oryginal/2017_01/c29e70c65b118a8944 82fc9eea33f35c.pdf) (2019, April 20).

10. Retrieved from (http://www.bip.nauka.gov.pl/g2/oryginal/2017_01/0e2788d2d4b19e1a7 54b0daf96ce7be7.pdf) (2019, April 20).

11. The database is available at the following address http://arianta.pl/.

12. Retrieved from (arainta.pl) (2019, April 22).

13. Retrieved from (https://wydawnictwo.uni.lodz.pl/redakcje-czasopism/acta-universitatis-lodziensis-folia-litteraria-polonica/). 
The annual publication concerns broadly understood social communication, communication research, media and their social and cultural functions ${ }^{14}$;

- Cognitive Science - New Media - Education - this is a bi-annual (also in the online version), and it has been published in English since 2016. It is being developed in Torun by scholars associated with the Nicolaus Copernicus University. The journal presents the latest researches and theoretical reflections on the cognitive aspects of Media Pedagogy and the use of new media in widely understood education, daily life, culture, art, education therapy and speech therapy, among others areas ${ }^{15}$;

- Comm.press - is an electronic quarterly journal edited by the Institute of Journalism, Media and Social Communication of the Jagiellonian University. The periodical appeared in 2018 and is a bi-monthly journal. - Comm.press publishes articles in the fields of media science, communication science as well as interdisciplinary articles ${ }^{16}$;

- Dziennikarstwo i Media (Journalism and Media) - a journal issued since 2011, is published by the Institute of Journalism and Social Communication of the University of Wrocław. Articles are also available in pdf version. The annual refers to broadly understood social communication, communication research, media and their social and cultural functions ${ }^{17}$;

- Fides, Ratio et Patria. Studia Toruńskie - a half-yearly magazine, published in Torun since 2014 by the College of Social and Media Culture. The periodical appears only in the printed version. The editorial team invites scholars from such fields as history, economics, political science, sociology, theology, philosophy, media studies, cultural studies, social communication and literary studies and $\mathrm{IT}^{18}$;

- Global Media Journal. Edycja polska (Global Media Journal. Polish edition) The magazine has been published since 2006 by Collegium Civitas in Warsaw. This is the Polish version of the media journal Global Media Journal (GMJ), published in the USA by Purdue University. The magazine is available online. Research areas are: media, social communication and public relations. The last available issue is from $2015^{19}$;

14. Retrieved from (http://dzm.wuwr.pl/).

15. Retrieved from (http://apcz.umk.pl/czasopisma/index.php/CSNME/index).

16. Retrieved from (https://compress.edu.pl).

17. Retrieved from (http://dzm.sjol.eu/catalog/-16).

18. Retrieved from (http://wsksim.edu.pl/fides-ratio-et-patria-studia-torunskie/).

19. Retrieved from (http://www.globalmediajournal.collegium.edu.pl/od-redaktora.htm). 
- Kultura Media Teologia (Culture Media Theology) - it is an academic quarterly available only in an online version. The periodical is published by the Institute of Media Education and Journalism of the Cardinal Stefan Wyszyński University in Warsaw. The editors publish texts in the fields of media studies, journalism and social communication ${ }^{20}$;

- Kwartalnik Nauk o Mediach (Academic Quarterly Media) - is a periodical, which appeared only in the online version from 2015. The publication was suspended on March 1, 2018. The quarterly was published by the University of Cardinal Stanisław Wyszyński at the Faculty of Theology in the Institute of Media Education and Journalism. Research areas were: media studies, journalism, social communication ${ }^{21}$;

- Media-Kultura-Komunikacja Spoleczna (Media-Culture-Social Communication) - the journal has been published since 2005. It is a quarterly (also available in an online version) published at the University of Warmia and Mazury in Olsztyn. The journal is edited by the Institute of Journalism and Social Communication. The profile of the journal assumes the study of the media spectrum and methodological diversity ${ }^{22}$;

- Media i Medioznawstwo (Media and Media Studies) - this is a quarterly journal that was issued in 2011-2014. It was edited by Wydawnictwo Naukowe Scriptorium (Scriptorium Academic Publishers) in Opole. The periodical was available only in paper form. It focused on the media and media studies in general sense $\mathrm{e}^{23}$;

- Media i Spoleczeństwo (Media and Society) - a journal (annual) which has been published since 2011 on behalf of the University of Technology and Humanities in Bielsko-Biała. The areas touched upon in the publications includes: communication, semiology, media sociology and media pedagogy ${ }^{24}$;

- Media, Biznes, Kultura (Media, Business, Culture) - a half-yearly, published since 2016 at the University of Gdańsk. It is edited by the Institute of Philosophy, Sociology and Journalism. The research areas are: media studies, communication, semiotics and media sociology; ${ }^{25}$;

20. Retrieved from (https://kmt.uksw.edu.pl/).

21. Retrieved from (http://knm.uksw.edu.pl/).

22. Retrieved from (http://uwm.edu.pl/mkks/).

23. Retrieved from (http://www.scriptorium.net.pl/?sekcja=produkty\&opcja=kategoria\&id=1 7).

24. Retrieved from (http://www.mediaispoleczenstwo.ath.bielsko.pl/).

25. Retrieved from (http://www.ejournals.eu/MBK/). 
- Mediatization Studies - is a half-yearly journal, published in English by the Maria Curie-Skłodowska University from 2017. It focuses on media science and media communication ${ }^{26}$;

- Nowy Przeglad Dziennikarski (New Journalism Review) is a quarterly magazine, edited since 2012 by the Association of Journalistic Studies in Rzeszów. The research area is broadly understood journalism ${ }^{27}$;

- Nowe Media (New Media) - is a yearly journal issued since 2010 on behalf of the Nicolaus Copernicus University of Torun. It is prepared by the Department of Journalism and Social Communication, and published by the Institute of Journalism and Social Communication of the University of Wrocław. The editors deal with research on social communication, journalism, sociology and political science. The last issue of the magazine in a digital version was released in $2014^{28}$;

- Replay. The Polish Journal of Game Studies - an annual, which has been published in English since 2014 at the University of Lodz. The editorial sections include culture, sociology and philosophy ${ }^{29}$;

- Studia Medioznawcze (Media Studies) is a quarterly journal of the Faculty of Journalism, Information and Bibliology of the University of Warsaw, focusing on broadly understood media studies, which was set up in 2000 at the Institute of Journalism at the Faculty of Journalism and Political Sciences of the University of Warsaw. The texts are published and made available on the quarterly's website ${ }^{30}$.

It should be emphasized that only current journals have been selected for the needs of the following publication. Among them are periodicals appearing both in printed and electronic versions and such available only on the web. The analyzed numbers come from the latest (available in digital version) editions of academic periodicals. These include: Acta Universitatis Lodziensis. Folia Litteraria Polonica (the date analysed is from 2018), Acta Universitatis Wratislaviensis. Journalism and Media (analyzed numbers come from 2017), Cognitive Science - New Media - Education (from 2016), Comm.press (from 2018), Journalism and Media (from 2017), Culture Media Theology (from 2019), Media-Culture-Social Communication (from 2018), Media and Society (analyzed numbers from 2018 year), Media, Business, Culture (research

26. Retrieved from (https://journals.umcs.pl/ms).

27. Retrieved from (http://www.naukowy-przeglad-dziennikarski.org/).

28. Retrieved from (http://www.nowemedia.umk.pl/).

29. Retrieved from (http://www.replay.uni.lodz.pl/about.html).

30. Retrieved from (http://studiamedioznawcze.pl/). 
numbers come from 2018), Mediatization Studies (from 2018), New Journalism Review (from 2018), Replay. The Polish Journal of Game Studies (from 2016) and Media Studies (from2018).

\section{Results/Key Findings. Discussion of Finding}

The analysis of the selected issues of the academic journals available on the Internet indicates that only selected journalistic genres appear in their pages. Among them we can distinguish: academic articles, reviews and reports. There are neither polemics ${ }^{31}$ nor chronicles ${ }^{32}$ in the examined issues.

\subsection{Academic articles}

Among the communication genres belonging to academic discourse, the academic article occupies a particularly privileged place. It is the most popular genre appearing in the pages of academic journalism. It is considered an elementary means of communication between scientists around the world. It serves the consolidation and dissemination of new and original knowledge obtained as a result of the conducted research. When talking about the structure of an academic article, one should distinguish its paratextual elements, i.e. subsidiary texts, which include: title, author's details (name and surname, academic title, affiliate academic institution, contact details, personal note/ academic biography), keywords, abstract, summary, index of names and footnotes. Abstracts and key words should most often be recalled in English or another common language indicated by the editors. Each academic article is accompanied by a bibliography of academic papers that served in the presentation of the current state of knowledge or were cited in the text. While observing

31. A polemic is an intertextual statement, constituting a critical reaction to the opinion of another author. Polemics allows the presenting of positions, the pointing out of points of disagreement, the confronting of views, sometimes showing the rightness of some of them, thus influencing public opinion and inspiring recipients to independent thinking (Słownik terminologii medialnej (Dictionary of media terminology), 2006, p. 151). It can be persuasive and it usually uses eristic techniques, which distinguishes it from the voice of factual discussion. Polemics is also a way of conducting a dispute, in which participants are not so much partners, intending to determine the situation and work out a consistent position, but rather rivals, seeking to convince others of their reasons and demonstrate the skill of verbal fencing. The order of referenced arguments usually results from the logic of reasoning presented in the inspirational text, however the author uses it to show his own way of seeing the problem and he does not limit himself to undermining the opponent's arguments.

32. The chronicle is one of the informational journalistic genres, containing chronologically ordered information on a given issue. It can be independent journalistic material or a separate supplement to journalistic material (Słownik terminologii medialnej (Dictionary of media terminology), 2006, p. 107). The academic journals in the chronicle contain information on academic events. 
copyrights and respecting the intellectual property of other researchers, it is necessary to clearly distinguish segments of the author's own statements from cited segments (the statements of others).

The Act on Copyright and Related Rights states that it is permissible to cite in works constituting an intrinsic whole, extracts of disseminated works or small works in their entirety within the scope justified by an explanation, critical analysis, teaching or the law of the genre of creativity (Wolański, 2008, p. 198).

In the academic article we deal with "communication characterized by elitism" (Wojtak 2015, p. 65), that is, the article is addressed to specific recipients. They are bound by a community of knowledge and interests captured by Maria Wojtak in the formula "their talk to their own, enthusiasts communicate with enthusiasts" (Wojtak, 2015, p. 65). There is common knowledge between the sender of the article and its recipients, which allows the use of specialist terms and concepts to facilitate free movement within one discipline. Each branch of science has developed its own conceptual instruments, and their use serves the precise and economical communication between scientists.

It should be added that the main function of the academic article is to inform. Taking into account the theory of speech acts, the academic article is an act of assertion, or declaration. The intention of the sender is to build a text that coherently transmits intellectual material.

When writing an academic article, one should constantly keep in mind the potential recipient and use such words and sentence constructs that will reliably convey one's thoughts and intentions. Correct and efficient communication, free from language errors and complying with accepted standards, is of no less importance than knowledge and interests connecting the sender and the recipient. An understandable and interesting academic article gives an opportunity to engage the recipient and start a discussion.

Academic articles are a permanent element of all selected academic journals. Examples include: Motywy podróży w reportażu radiowym (Travel themes in radio reports) by Joanna Bachura-Wojtasik, Kinga Sygizman (Acta Universitatis Lodziensis. Folia Litteraria Polonica, 2018, No. 5, pp. 11-29); Reprezentacja zawarta $w$ odbiciu (Representation contained in reflection) by Jerzy Olek (Acta Universitatis Wratislaviensis Journalism and Media, 2017, No. 8, pp. 1728); and The dictatorship of democracy or democratic dictatorship in the new media by Sabahudin Hadzialić (Cognitive Science - New Media - Education, 2016, No. 1, pp. 11-25). In addition, Personalizacja internetu - zagrożenia czy naturalny proces rozwoju sieci? (Personalization of the Internet - a threat or the natural process of network development?) by Monika Jabłońska (Comm. press, 2018, No. 1, pp. 56-71); Dyskursywny obraz mitości w tekstach disco polo 
$z$ lat 2014-2016 (A discursive picture of love in disco polo texts from 2014-2016) by Jakub Łączniak (Journalism and Media, 2017, No. 8, pp. 79-100); as well as Analiza zjawiskowa katolickiej blogosfery w Polsce w kontekście jej rozwoju profesjonalizmu (Analysis of the phenomenon of the Catholic blogosphere in Poland in the context of its professional development) by Karolina Padlewska (Culture Media Theology, 2019, No. 1 (36), pp. 30-49) and O krótkich formach internetowych zachęcajacych do kliknięcia (Short internet forms as clickbait) by Izabela Ławecka (Media-Culture-Social Communication, 2018, No. 14, pp. 51-62). Other examples include: Dialog obywatelski w Krakowie. Reprezentacje medialne aktorów dialogu obywatelskiego (Public dialogue in Krakow. Media representation of actors in public dialogue) Joanna Grzenik (Media and Society, 2018, vol. 9, pp. 21-32); Wieczorne serwisy informacyjne a ksztaltowanie opinii (Evening information services and the shaping of opinion) by Klaudiaa Kamieniarz (Media, Business, Culture, 2018, No. 2 (5), pp. 1123). In addition, there are: The present in mediatization studies by Łukasz Wojtkowski (Mediatization Studies, 2017, No. 1, 2017, pp. 9-22) and Dialog, monolog, interakcja? Portal społecznościowy jako kanat komunikowania online samorzadu gminnego. Studium przypadku miasta Kielce Dialog, monologue, interaction? (A social networking site as an online communication channel for the municipal government. A case study of the city of Kielce), Krzysztof Kowalik (New Journalism Review, 2018, No. 1, pp. 7-25). The academic article is an inseparable element of the two remaining research journals: David Chircop's $A n$ Experiential Comparative Tool for Board Games (Replay, The Polish Journal of Game Studies, 2016, No. 1 (3), pp. 11-28), as well as Komunikowanie społeczne i media - federacja, a nie inkorporacja (Social Communication and media federation, not incorporation) by Marek Jabłonowski and Tomasz Mielczarek (Media Studies, 2018, No. 4 (5), pp. 13-30).

\subsection{Reviews}

An academic review is a review of an academic work (dissertation, book, publication in an academic journal), which aims to evaluate the academic content of this work. It is written by a scientist specializing in a given field of knowledge. It is an evaluative and informational text, characterized by the topicality of the theme and the clear subjectivity of opinion. The aim of the review is also to send the recipient postulates - "for" or "against", so it should be the starting point of the conversation about the academic publication. The reader who accesses the review expects information about what the work is about, help in understanding it and clearly formulated assessments (Worsowicz, 2006, p. 52). 
The vocabulary of the review is characterized by the high frequency or at least the definite presence of words and judgments evaluating, evaluating and expressing (Encyklopedia wiedzy o prasie [Encyclopedia of knowledge about the press], 1976, p. 209).

The task of the review is to eliminate publications that put forward theses that are not covered in the description of the conducted experiments or collected historical data. The reviewing of academic papers is aimed at ensuring a high standard of science - provided the integrity and respect of ethical standards relevant to this process are maintained.

Academic reviews do not appear regularly in every issue of a periodical. This genre appears sporadically. In the analyzed issues one can distinguish: Algorytmy wobec demokracji (Algorithms in the face of democracy) by Anna Łozowska $^{33}$ (Media-Culture-Social Communication, 2018, No. 14, pp. 105-114), Tygodniki opinii $w$ zmieniajacej się rzeczywistości (Weeklies' opinions in the changing reality) ${ }^{34}$ by Olga Dąbrowska-Cendrowska (Media and Society, 2018, vol. 9, pp. 263-267) and the review ${ }^{35}$ of Katarzyna Maciejewska-Mieszkowska (Media, Business, Culture, 2018, No. 2 (5), pp. 199-201). Examples of reviews also include: Ewa Nowak-Teter's review of How to Do Critical Discourse Analysis by David Machin and Andrea Mayr, Sage, Los Angeles 2012, p. 236 (Mediatization Studies, 2017, No. 1, pp. 105-108) and Ile emersji w grach (How much emersion in games) ${ }^{36}$ by Stanisław Krawczyk (Replay. The Polish Journal of Game Studies, 2016, No. 1 (3), pp. 156-161). Reviews can also be found in Media Studies. An example of this is Fenomen reklamy religijnej (The phenomenon of religious advertising) ${ }^{37}$ by Wojciech Jakubowski (Media Studies, 2018, No. 4 (5), pp. 131-134) and Książka. Najpotężniejszy przedmiot naszych czasów zbadany od deski do deski (The Book. The most powerful object

33. Review of the book Jak Facebook oddala nas od siebie i zagraża demokracji (How Facebook Dooms Away from Us and Endangers the Democracy) by Siva Vaidhyanathan from 2018 published by Antisocial Media with translation by Weronika Mincer and Katarzyna Sosnowska - Warsaw: Grupa Wydawnicza Foksal, pp. 322.

34. Review of Tomasz Mielczarek’s book Tygodniki opinii w zmieniającej się rzeczywistości (Weeklies' opinions in the changing reality) of 2018, pp. 260.

35. Review of the book by Weronika Świerczyńska-Głownia titled Działalność programowa telewizji publicznej. Kluczowe determinanty programowania i dystrybucja oferty (Programming activity of public television. Key determinants of programming and distribution of the offer) of 2017, pp. 321.

36. A review of Piotr Kubiński's book Gry wideo. Zarys poetyki (Video games. Outline of poetics) of 2016, pp. 113.

37. A review of the book by Krzysztof Stępniak Fenomen reklamy religijnej (The phenomenon of religious advertising) of 2017, pp. 283. 
of our time, examined from cover to cover $)^{38}$ by Kalina Kukiełko-Rogozińska (Media Studies, 2018, No. 4 (5), pp. 135-139).

\subsection{Reports}

A report is a presentation of exceptional events (in this case academic) that have already culminated in their finale. The characteristic feature is presenting the facts in a dynamic manner, in a timely order, faithfully if possible, while keeping the chronological sequence of events as mandatory. The report is not characterized by the persons participating in the event; it is limited only to giving first and last names, titles, functions and positions held. You can also interlace the text with the characters' statements as well as summaries of their public appearances. The report is characterized by presenting events from many points of view to maintain objectivity (often the statements of the presented characters are given) (Stownik terminologii medialnej (Dictionary of media terminology), 2006, p. 201).

The report appears sporadically in the Kultury Mediów Teologii (Culture of Theological Media). This genre is placed in the "Information" section. Examples include the report from the academic conference on "Oryginat $i$ kopia. Znikajaca tożsamośc" ("Original and copy. Disappearing identity"), which took place on October 19, 2011 in the John Paul II Hall at the UKSW campus in Warsaw. The conference website was also presented on the website of the journal; the composition of the organizing committee and the academic council were showed $^{39}$, as well as a report from the academic conference that took place on May 14, 2010 at the UKSW campus on 5 Dewajtis Street as part of the Wyzwania nowych mediów (New Media Challenges) series on Etyczne i prawne wyzwania Internetu (Ethical and Legal Internet Challenges). The organizer of the session was the Department of Media Pedagogy, headed by prof. dr hab. Krystyna Czuba. The editors of the conference report made a short description of the deliberations in individual sections ${ }^{40}$. Reports from conferences can also be found in the Media Studies. An illustration of this are two examples: A report on the 3rd International Conference \& Media Studies, Berkeley, 18-19 October 2018 Karolina Brylska, Tomasz Gackowski, Anna Mierzecka (Media Studies, 2018, No. 4(5) , pp. 121-125), as well as a report from the international conference "Sprawiedliwe wynagradzanie $w$ opinii współczesnych pracowników" "Fair

38. Book review of Książka. Najpotężniejszy przedmiot naszych czasów zbadany od deski do deski (The Book. The most powerful subject of our time, examined from cover to cover) by Keith Houtson, translated by Paweł Lipszyc from 2017, pp. 464.

39. Retrieved from (https://kmt.uksw.edu.pl/konferencja-oryginal-i-kopia-tekst) (2019, April 23).

40. Retrieved from (https://kmt.uksw.edu.pl/konferencja-oryginal-i-kopia-tekst) (2019, April 23). 
remuneration in the opinion of contemporary employees", Warsaw, October 1819, 2018 Agata Kostrzewy (Media Studies, 2018, No. 4 (5), pp. 126- 128).

\section{Conclusion}

Academic journals are one of the main communication channels in science, being a platform for the exchange of researchers' thoughts not only from Poland, but from around the world. Initially, they appeared in the form of printed volumes, to which academic institutions and individual scholars aspired. A huge increase in the number of publications meant that institutions began to look for ways to identify those with the greatest impact on the academic environment, because these institutions were not able to collect all the journals appearing in a given field. At the same time, the environment of science changed, new possibilities of recording and sending content (digital media and the Internet) appeared, which were used by the publishers to create electronic and hybrid journals, i.e. printed in both paper and electronic form. There were also citation indexes, covering journals that meet many different criteria. Citation indexes, as part of such websites as Scopus or Web of Science, perform several functions. First of all, they make it easier for scholars to reach articles and magazines, not only through the use of key words, but also thanks to links placed on quoted and cited objects (authors, articles, magazines). Secondly, they show which articles and magazines are the most appreciated in the academic community. Thirdly, they support the evaluation of science. They play one more important role - they raise the editorial and publishing standards of academic journals.

\section{References:}

(2019, March 19). Fides, Ratio et Patria. Studia Toruńskie. Retrieved from http:// wsksim.edu.pl/fides-ratio-et-patria-studia-torunskie/

(n.d.). Konferencja naukowa pt. “Oryginał i kopia. Znikająca tożsamość”. Retrieved from https://kmt.uksw.edu.pl/konferencja-oryginal-i-kopia-tekst

(n.d.). książki niezwykłe... Retrieved from http://www.scriptorium.net.pl/?sekcja=prod ukty\&opcja=kategoria\&id $=17$

(n.d.). NAUKOWE I FACHOWE POLSKIE CZASOPISMA ELEKTRONICZNE. Retrieved from http://arianta.pl/

(n.d.). Naukowy Przegląd Dziennikarski: Journalism Research Review Quarterly. Retrieved from http://www.naukowy-przeglad-dziennikarski.org/

(n.d.). Nowe Media. Retrieved from http://www.nowemedia.umk.pl/

(n.d.). Retrieved from http://apcz.umk.pl/czasopisma/index.php/CSNME/index

(n.d.). Retrieved from http://uwm.edu.pl/mkks/

(n.d.). Retrieved from http://www.replay.uni.lodz.pl/about.html

(n.d.). Retrieved from https://journals.umcs.pl/ms 
(n.d.). Rzecznik Praw Obywatelskich. Retrieved from https://www.rpo.gov.pl/ (n.d.). Rzecznik Praw Obywatelskich. Retrieved from https://www.rpo.gov.pl/

(n.d.). Strona główna - Com.press - czasopismo naukowe. Komunikacja i nauki o mediach. Retrieved from https://compress.edu.pl/

(n.d.). Studia Medioznawcze - Strona główna / Index Page. Retrieved from http:// studiamedioznawcze.pl/

(n.d.). Wizerunek w mediach. Retrieved from https://kmt.uksw.edu.pl/

Acta Universitatis Lodziensis. Folia Litteraria Polonica. (2018). vol. 51, No 5.

Acta Universitatis Wratislaviensis. Dziennikarstwo i Media. (2017). No. 8.

Bajka, Z. (2000). Dziennikarze lat dziewięćdziesiątych. Zeszyty Prasoznawcze. Vol. 3-4.

Bajka, Z. (2000). Reklama w mediach. Dziennikarstwo i świat mediów. pp. 374-388. Cracow.

Bajka, Z. (2012). Rynek mediów w Polsce. Dziennikarstwo i świat mediów, Chudziński E., Bauer Z. (Ed.). Cracow.

Bauer, Z. (2015). Gatunki dziennikarskie w Sieci. Co się zmieniło i jak bardzo?. In E-gatunki. Dziennikarz w nowej przestrzeni edukacyjnej. Godzic W., Bauer, Z. (Ed). Warsaw.

Cognitive Science - New Media - Education. (2016). No. 1

Comm.press. (2018). No. 1.

Czasopismo Naukowe "Kultura i Historia". (n.d.). Retrieved from http://www. kulturaihistoria.umcs.lublin.pl/czasopismo

Czulak, J. (n.d.). Numer dziesiąty: Retrieved from http://www.mediaispoleczenstwo. ath.bielsko.pl/

Dzieje prasy polskiej. (1988), Łojek J., Myśliński J., Władyka W., Warsaw.

Dziennikarstwo i Media. (2017). No. 8.

Encyklopedia wiedzy o prasie. (1976). Maślanka J. (Ed.). Wrocław - Warsaw Cracow.

Filas, R. (1999). Dziesięć lat przemian mediów masowych w Polsce (1989-1990). In Zeszyty Prasoznawcze. vol. 1-2.

Fiut, I. (2000). Pisma społeczno-kulturalne w latach 1989-2000. In Zeszyty Prasoznawcze. Vol. 3-4.

Hombek, D. (2016). Dzieje prasy polskiej do 1795 roku. Kielce.

Jarowiecki, J. (1995). Transformacja prasy polskiej w latach 1989-1994, Prace Naukowe Uniwersytetu Śląskiego 1995. 1525, Katowice.

Kultura Media Teologia. (2019). No. 1 (36).

Łojek J., (Ed.). Prasa polska 1661-1864. (1976). Warsaw.

Łojek J., (Ed.). Prasa polska 1864-1918. (1976). Warsaw.

Łojek J., (Ed.). Prasa polska 1918 - 1939. (1980). Warsaw.

Media i Społeczeństwo. (2018). vol. 9. 
Media, Biznes, Kultura. (2018). No. 2 (5).

Media-Kultura-Komunikacja Spoleczna. (2018), No. 14.

Mediatization Studies. (2017). vol. 1, No. 1.

Nowy Przeglad Dziennikarski. (2018). No. 1.

Oniszczuk. Z. (2010). Strefy wpływu kapitału niemieckiego w polskich mediach . In Prawo, etyka czy rynek? Zmiany w polskich mediach po 1989 roku. Torun.

Pisarek, W. (Ed.). Stownik terminologii medialnej. (2006). Cracow.

Prasa polska 1939-1945. (1980., Łojek J., (Ed.) Warsaw.

Replay. The Polish Journal of Game Studies. (2016). No. 1 (3).

Studia Medioznawcze. (2018). No. 4 (5).

Wojtak, M. (2004). Gatunki prasowe. Lublin.

www.npc.pl, N. P. C. (n.d.). Ministerstwo Nauki i Szkolnictwa Wyższego. Retrieved from http://www.bip.nauka.gov.pl/ 